\title{
Characterisation of alheiras, traditional sausages produced in the North of Portugal, with respect to their microbiological safety
}

\author{
Vânia Ferreira a, Joana Barbosa ${ }^{\text {a }}$, Joana Silva a , Maria Teresa Felício a,b, Cristina Mena ${ }^{\text {a }}$, \\ Tim Hogg a , Paul Gibbs ${ }^{\text {a,c }}$, Paula Teixeira ${ }^{\text {a,* }}$ \\ ${ }^{a}$ Escola Superior de Biotecnologia, Universidade Católica Portuguesa, R. Dr António Bernardino de Almeida, 4200-072 Porto, Portugal \\ ${ }^{\mathrm{b}}$ Escola Superior Agrária, Instituto Politécnico de Castelo Branco, 6001-909 Castelo Branco, Portugal \\ ${ }^{\mathrm{c}}$ Leatherhead Food International, Surrey, KT22 $7 R Y, U K$
}

Keywords: Fermented sausages; Alheira; Pathogens

\begin{abstract}
The objective of this study was the characterisation of alheiras, traditional Portuguese sausages, with respect to their microbiological safety. Thirty-eight lots from 17 producers were analysed. The microbiological status of the analysed product can be considered of concern in terms of food safety. Although Campylobacter spp. and Escherichia coli O157 were not detected in any sample, and Clostridium perfringens when present was not at levels of concern with reference to public health, Salmonella spp. were detected in 2 lots of industrially produced alheiras, and more than $60 \%$ of the lots analysed were contaminated with Listeria monocytogenes in concentrations higher than $100 \mathrm{cfu} / \mathrm{g}$.
\end{abstract}

\section{Introduction}

Fermented meat products are part of the daily diet in rural areas of Portugal and fashionable food products in urban centres whose market has been increasing in a significant way. Consumers consider traditional fermented sausages safe foods. The simultaneous reduction in the $a_{\mathrm{w}}$ and $\mathrm{pH}$ partially inhibits the development of pathogenic bacteria during the various stages of sausages manufacture. However, as raw meats are frequently contaminated, there is a probability that some of the pathogenic organisms could cross the antimicrobial barriers imposed during processing. Therefore, they may be present in the final product, causing a concern for the producers and for those responsible for public health, and has been the topic of study of sev-

* Corresponding author. Tel.: +351 22 5580095; fax: +351 22 5580111/ 5090351.

E-mail address: paula@esb.ucp.pt (P. Teixeira). eral research groups. Post-process recontamination is another possibility. The presence of pathogens in fermented sausages has been previously reported (Ananou et al., 2005; Samelis \& Metaxopoulos, 1999; Thévenot, DelignetteMuller, Christieans, \& Vernozy-Rozand, 2005).

Indeed, the importance of fermented meats being a source of pathogens, thereby resulting in outbreaks was highlighted by Moore (2004).

In addition to Salmonella, Staphylococcus aureus and Clostridium botulinum, the microorganisms mainly studied in these products in the past decades (Tompkin, Christiansen, Shaparis, \& Bolin, 1974), Listeria monocytogenes and Escherichia coli $\mathrm{O} 157: \mathrm{H} 7$ are the predominant pathogens currently under study (Hew, Hajmeer, Farver, Glover, \& Cliver, 2005; Naim, Messier, Saucier, \& Piette, 2004; Pond, Wood, Mumin, Barbut, \& Griffiths, 2001; Samelis, Kakouri, Savavvaidis, Riganakos, \& Kontominas, 2005).

Alheiras are traditional smoked fermented meat sausages produced in the North of Portugal. In addition to the homemade alheiras, more than 500 tonnes are annually 
produced by various commercial industrial plants (http:// www.idrha.min-agricultura.pt/produtos_tradicionais/estatisticas/estatisticas.htm), using pork and other type of meats (duck, turkey, chicken, partridge and calf), representing an important economic resource for the region.

For the production of alheiras, the various meats are boiled in water with salt and spices. Bread is thinly sliced and immersed in some of the broth formed during the boiling of the meats and when it is soft enough, meat in small pieces, spices and olive oil and/or fat drippings are added to the mixture. When everything is completely mixed the paste is stuffed into cattle intestinal casings and submitted to a dry smoke process, usually for no longer than eight days. In previous work, a preliminary chemical and microbiological characterization of alheiras was made. In general, the results obtained have shown that the optimization of hygienic procedures in the process of production is necessary to improve the quality and safety of alheiras (Ferreira et al. (submitted for publication)). Therefore, the objective of this study was the characterisation of alheiras, with respect to their microbiological safety. The generated data are intended to contribute to the determination of the risk that these products might present to consumers.

\section{Materials and methods}

Alheiras from 17 different producers were collected from retail establishments. Of these producers, 12 are designated industrial producers (producers 1-12) and five "Cozinhas Regionais de Fumeiro", (producers 13-17) hereafter referred small artisanal producers (SAPs) which are small units that cannot transform more than $3000 \mathrm{~kg}$ of raw material per year into smoked meats, and are obliged to commercialize their products within a maximum radius of $40 \mathrm{Km}$. With the exception of 2 specific industrial producers and of those from SAPs, which were only sampled once, samples were collected on at least two different occasions in order to have representatives from more than one batch. Samples were transported to the laboratory in portable, insulated cold-boxes and stored at $4{ }^{\circ} \mathrm{C}$ until analysis, normally between 1 and 5 days after collection. From each batch, 6 alheiras were divided into various pieces. For each parameter to be evaluated, unless otherwise stated, 2-4 independent analyses were performed using randomly selected pieces.

Twenty-five grams samples were added to $225 \mathrm{ml}$ of sterile buffered peptone water (Merck, Darmstadt, Germany), and homogenized in a stomacher for $2 \mathrm{~min}$. Appropriate decimal dilutions were prepared in Ringer's solution (LabM, Bury, UK) for microbial enumeration: E. coli on TBX (BioRad, CA, USA), incubated at $44^{\circ} \mathrm{C}$ for $24 \mathrm{~h}$; coagulase-positive staphylococci on Baird-Parker RPF-agar (bioMérieux, Marcy l'Etoile, France), incubated at $37^{\circ} \mathrm{C}$ for $48 \mathrm{~h}$; Enterobacteriaceae according to ISO 21528-2 Anonymous, 2004a; enumeration of Clostridium perfringens was performed according to the European Standard EN 13401 (Anonymous, 1999).

Detection of E. coli $\mathrm{O} 157$ was performed by ImmunoMagnetic Separation using Dynabeads® (Dynal A.S, Oslo,
Norway) coated with absorbed and affinity purified antiE. coli $\mathrm{O} 157$ antibodies according to the International Standard, ISO 16654 (Anonymous, 2001b).

Detection of Campylobacter was performed using the VIDAS Campylobacter-method CAM (bioMérieux; Anonymous, 2004b) which is an enzyme-linked fluorescent immunoassay performed in the automated VIDAS instrument, using antibody specific for Campylobacter jejuni, $C$. coli and C. lari. C. upsaliensis is not detected by this method. Campylobacter was also detected according to the ISO/DIS 10272-1 standard (Anonymous, 2001a) using as selective isolation media mCCD agar (Oxoid CM 739) and Karmali agar (Oxoid CM 935). L. monocytogenes was also detected by the VIDAS method (Anonymous, 1996) and direct enumeration of this species was performed according to the International Standard ISO 11290-2 (Anonymous, 1998).

Salmonella spp. was also detected by the VIDAS method (Anonymous, 1994). Confirmation of positive results was performed using as enrichment broths RVS and MKTT according to the standard techniques described in ISO 6579 (Anonymous, 2002).

\section{Results}

Thirty-eight lots of alheiras, 33 lots of 12 industrial producers and 5 lots from SAPs were analysed.

E. coli $\mathrm{O} 157$ and Campylobacter spp. were not detected in any of the lots analysed.

Salmonella spp. was found in two lots, (1 from producer 1 and the other from producer 6).

Results obtained for other organisms are presented in Table 1.

Each lot was classified as satisfactory, acceptable, unsatisfactory or potentially hazardous depending on the level and type of contamination, following the Guidelines of the Food Safety Authority of Ireland (Food Safety Authority of Ireland, 2001). As observed in Fig. 1, 20\% of alheiras produced in industrial plants, were classified as satisfactory and $30 \%$ and $50 \%$, were considered as unsatisfactory or potentially hazardous, respectively. $80 \%$ of the alheiras produced by SAPs were classified as unsatisfactory and $20 \%$ as potentially hazardous. The percentage of each organism or group of organisms that contributed to this classification is presented in Fig. 2 for the unsatisfactory lots and Fig. 3 for potentially hazardous lots.

\section{Discussion}

There are still no official microbiological criteria for fermented meats. Alheiras are normally cooked before consumption either by frying, grilling or boiling. However, studies by our research team in which the heating profile of alheiras during real scenarios of cooking by various consumers was monitored, suggest internal temperatures may often not be sufficient to kill all of the pathogens originally present (data not shown). In this context, alheiras can be 
Microbiological quality of alheira $(\log \mathrm{cfu} / \mathrm{g})$

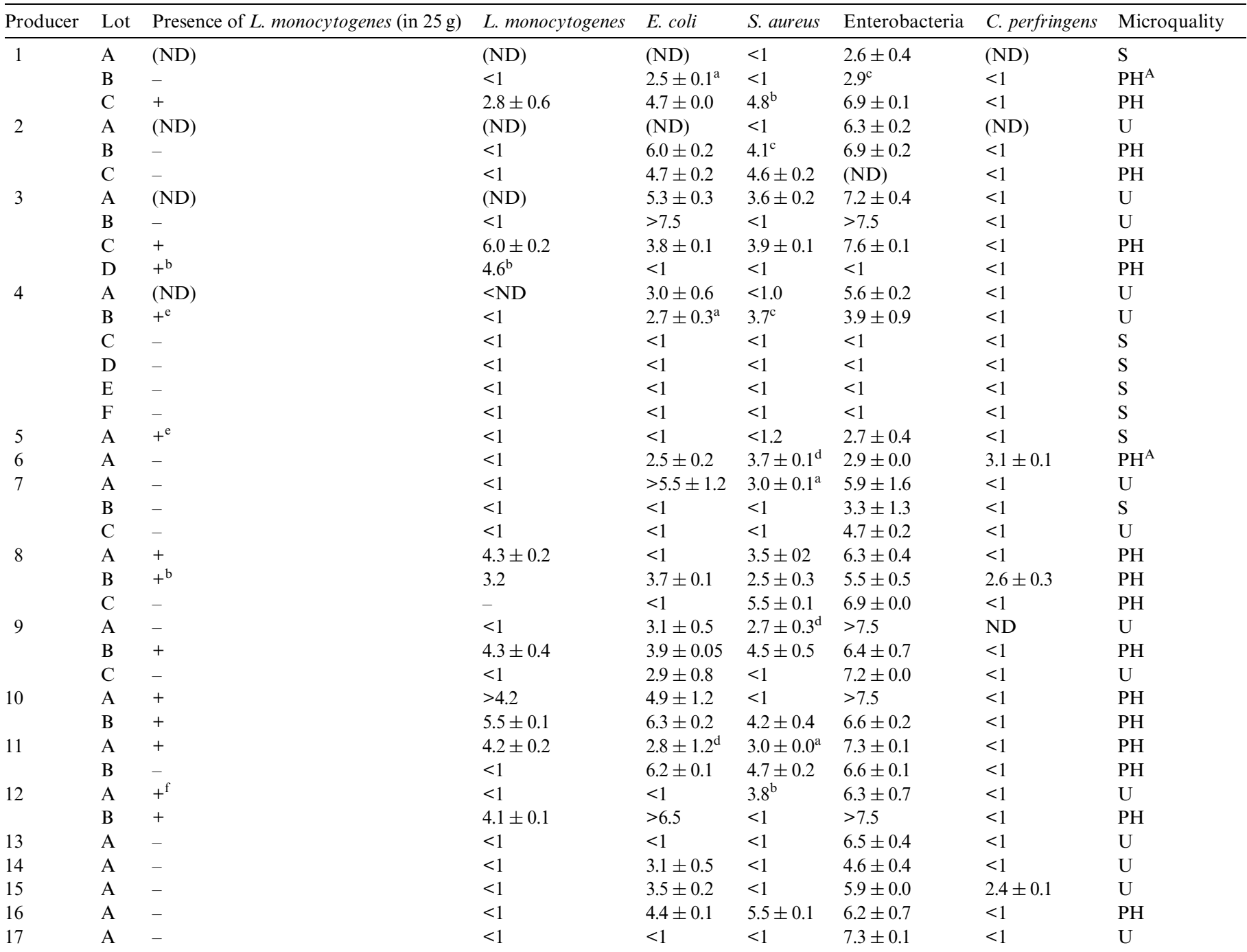

ND, Not determined; S, satisfactory; U, unsatisfactory; $\mathrm{PH}$, potentially hazardous.

${ }^{\text {A }}$ Classified as $\mathrm{PH}$ due to the presence of Salmonella spp.

a Media of two independent samples. Not detected in the two other independent samples.

b Value obtained for one independent sample. Not detected in the other sample.

c Value obtained for one sample. Not detected in the other three samples.

${ }^{d}$ Media of three independent samples. Not detected in the other independent sample.

${ }^{\mathrm{e}}$ Positive in three independent samples. Negative in one independent sample.

${ }^{\mathrm{f}}$ Positive in two independent samples; negative in two independent samples.

included in the ready-to-eat foods category. Therefore, results obtained in this study were analysed on the basis of the Irish microbiological guidelines for fermented meat products (Food Safety Authority of Ireland, 2001).

The microbiological status of the analysed product can be considered of concern in terms of food safety. Although Campylobacter spp. and E. coli $\mathrm{O} 157$ were not detected in any sample, and $C$. perfringens when present was not at levels of concern with reference to public health, Salmonella spp. were detected in two lots of industrially produced alheiras, (25 g samples) and more than $60 \%$ of the lots analysed were contaminated with $L$. monocytogenes in concentrations higher than $100 \mathrm{cfu} / \mathrm{g}$. This organism is responsible for listeriosis, a severe infection particularly among the elderly, very young and immunocompromised individuals, and has also been associated with late-term miscarriages in pregnant women. The infectious dose for listeriosis is not known, however, under the levels of control which are currently being applied, the concentrations are considerably higher than those normally found in similar products (Thévenot et al., 2005). In SAPs, the designation of potentially hazardous was attributed to one lot, due essentially to the presence of more than $10^{4} \mathrm{cfu} / \mathrm{g}$ of $S$. aureus. L. monocytogenes was not found in any products from the SAPs. Other authors have also mentioned this tendency, i.e. higher contamination rates in larger plants than in small ones, and 


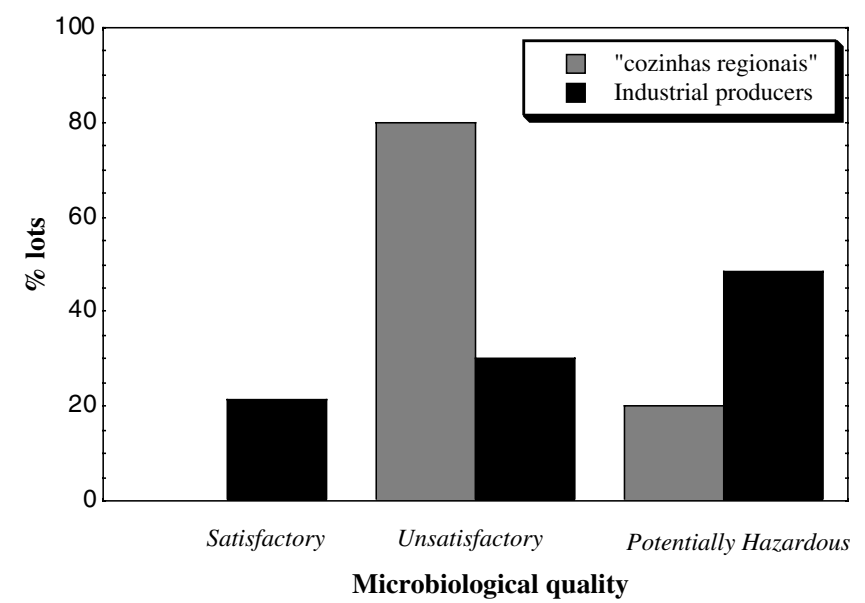

Fig. 1. Classification attributed to lots according to the Irish Guidelines (Food Safety Authority of Ireland, 2001).

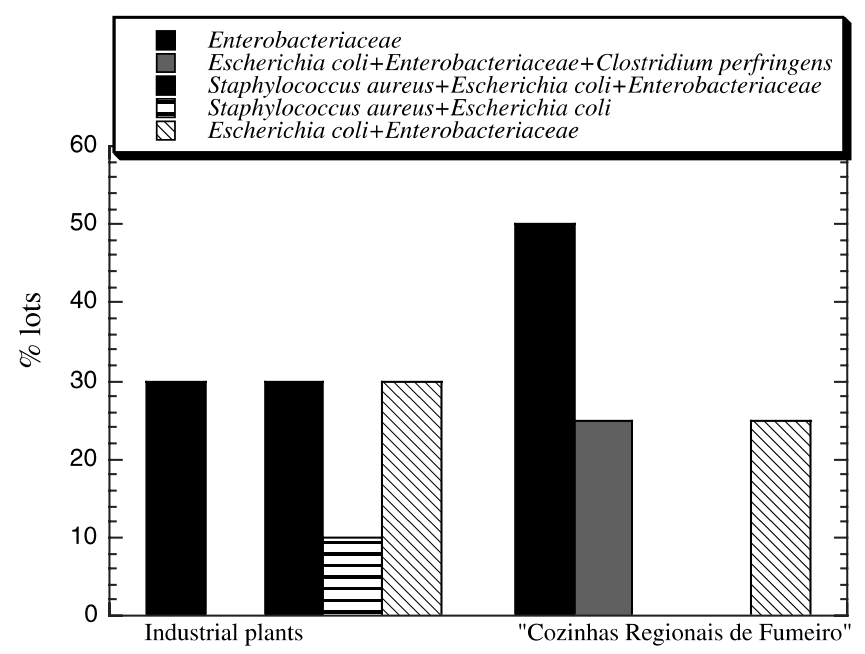

Fig. 2. Percentage of each organism or group of organisms that contributed to the classification of unsatisfactory.

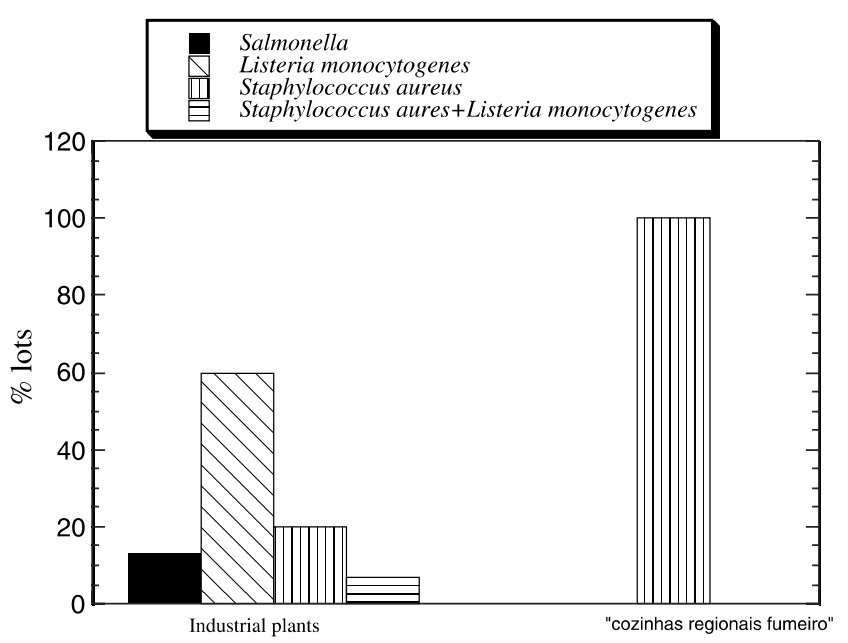

Fig. 3. Percentage of each organism or group of organisms that contributed to the classification of potentially hazardous. this has been attributed to the greater complexity of processing lines (Thévenot et al., 2005) where eradication of $L$. monocytogenes is difficult (Heir et al., 2004). In general, these potentially hazardous lots also had high microbial counts of the indicator organisms.

Lots classified as unsatisfactory generally presented high counts of Enterobacteriaceae, E. coli and S. aureus. In the case of Enterobacteriaceae and E. coli, this might be the result of poor hygiene or poor process control. High $S$. aureus concentrations are probably the result of the considerable levels of handling product-in-process, mainly the filling of the casings that in some plants is manual, or even cross-contamination. As the meats in this product are boiled sufficiently to remove the vegetative pathogen, the high microbial load found in the products might also result from post-process contamination via the addition of the bread or some spices after boiling; high levels of contamination of spices has been reported (Benerjee \& Sarkar, 2003, 2004).

The means of $\mathrm{pH}$, salt content and relative humidity of alheiras were reported by Ferreira et al. (submitted for publication) as $5.11 \pm 0.5,1.3 \pm 0.3 \%$ and $52.3 \pm 4.31 \%$, respectively. In a product with these characteristics, any contaminants will be able to grow specially if the product before filling or the final product is exposed to temperature abuses.

The findings of this study give cause for concern. However, we hope that producers consider it the motivation to improve the general hygienic conditions, to implement control systems, such as HACCP, and to try possible alterations in the technological process and suppliers of raw materials, especially of those that are added after boiling the meats. For example, the utilization of appropriate starter cultures would improve the acidity at the beginning of the process minimising the proliferation of pathogens. Various lactic acid bacteria having antimicrobial activity against L. monocytogenes and other pathogens, have already been isolated from various alheiras, and the possibility of them being used as starter cultures is currently being evaluated (data not shown). This would improve the product without altering its typical characteristics.

These improvements are urgent as it is predictable that a potential implication of alheiras in any serious food-borne disease would result in loss of consumer confidence in traditional products, thereby having an enormous economic impact.

\section{Acknowledgements}

This work was supported by FCT/FEDER project POCTI/AGG/39587/2001. Vânia Ferreira was financially supported by FCT/FEDER Project POCTI/AGG/39587/ 2001. Maria Teresa Felício was financially supported by PRODEP III (medida 5, acção 5.3). Associação Nacional de Criadores de Suinos de Raça Bísara (ANCSUB) was very helpful when establishing contacts with producers. 


\section{References}

Ananou, S., Garriga, M., Hugas, M., Maqueda, M., Martínez-Bueno, M., Gálvez, A., et al. (2005). Control of Listeria monocytogenes in model sausages by enterocin AS-48. International Journal of Food Microbiology, 103, 179-190.

Anonymous (1994). VIDAS Salmonella. AFNOR, Bio 12/1-04/94.

Anonymous (1996). VIDAS Listeria monocytogenes. AFNOR, Bio 12/3-03/ 96.

Anonymous (1998). Microbiology of food and animal feeding stuffsHorizontal method for the detection and enumeration of Listeria monocytogenes-Part 2: Enumeration method. International Standard ISO 11290-2/Amd1:2004

Anonymous (1999). Microbiology of food and animal feeding stuffsHorizontal method for the enumeration of Clostridium perfringens. Colonies count technique (ISO 7937: 1997 Modified). European Standard (EN 13401).

Anonymous (2001a). Microbiology of food and animal feeding stuffsHorizontal method for the detection and enumeration of Campylobacter growing at $41.5^{\circ} \mathrm{C}-$ Part 1: Detection method, Draft International Standard, ISO/DIS 10272-1.

Anonymous (2001b). Microbiology of food and animal feeding stuffsHorizontal method for the detection of Escherichia coli O157, International Standard ISO 16654

Anonymous (2002). Microbiology of food and animal feeding stuffsHorizontal method for the detection of Salmonella spp. International Standard, ISO 6579.

Anonymous (2004a). Microbiology of food and animal feeding stuffsHorizontal methods for the detection and enumeration of Enterobacteriaceae-Part 2: Colony-count method. International Standard ISO 21528-2.

Anonymous (2004b). Vidas Campylobacter, bioMérieux.

Benerjee, M., \& Sarkar, P. K. (2003). Microbiological quality of some retail spices in India. Food Research International, 36, 469-474.

Benerjee, M., \& Sarkar, P. K. (2004). Growth and enterotoxin production by sporeforming bacterial pathogens from spices. Food Control, 15, 491-496.

Ferreira, V., Barbosa, J., Vendeiro, S., Mota, A., Silva, F., Monteiro, M. J., et al. (submitted for publication). Chemical and microbiological char- acterization of alheira a typical Portuguese fermented sausage with particular reference to factors relating to food safety. Meat Science.

Food Safety Authority of Ireland (2001). Guidelines for the interpretation of results of microbiological analysis of some ready to eat foods sampled at the point of sale. Guidance Note No. 3. Available from (http:// www.fsai.ie/publications/index.asp).

Heir, E., Lindstedt, B., Røtteud, O., Vardund, T., Kapperud, G., \& Nesbakken, T. (2004). Molecular epidemiology and disinfectant susceptibility of Listeria monocytogenes from meat processing plants and human infections. International Journal of Food Microbiology, 96, 85-96.

Hew, C. M., Hajmeer, M. N., Farver, T. B., Glover, J. M., \& Cliver, D. O (2005). Survival of Listeria monocytogenes in experimental chorizos. Journal of Food Protection, 68, 324-330.

Moore, J. E. (2004). Gastrointestinal outbreaks associated with fermented meats. Meat Science, 67, 565-568.

Naim, F., Messier, S., Saucier, L., \& Piette, G. (2004). Postprocessing in vitro digestion challenge to evaluate survival of Escherichia coli O157:H7 in fermented dry sausages. Applied and Environmental Microbiology, 70, 6637-6642.

Pond, J. C., Wood, D. S., Mumin, I. M., Barbut, S., \& Griffiths, M. W. (2001). Modeling the survival of Escherichia coli $\mathrm{O} 157: \mathrm{H} 7$ in uncooked, semidry, fermented sausages. Journal of Food Protection, 64 , 759-766

Samelis, J., \& Metaxopoulos, J. (1999). Incidence and principal sources of Listeria spp. and L. monocytogenes contamination in processed meats and a meat processing plant. Food Microbiology, 16, 465-477.

Samelis, J., Kakouri, A., Savavvaidis, I. N., Riganakos, K., \& Kontominas, M. G. (2005). Use of ionizing radiation doses of 2 and $4 \mathrm{KGy}$ to control Listeria spp. and Escherichia coli $\mathrm{O} 157: \mathrm{H} 7$ on frozen meat trimmings used for dry fermented sausage production. Meat Science, 70, 189-195.

Thévenot, D., Delignette-Muller, M. L., Christieans, S., \& Vernozy-Rozand, C. (2005). Prevalence of Listeria monocytogenes in 13 dried sausage processing plants and their products. International Journal of Food Microbiology, 102, 85-94.

Tompkin, R. B., Christiansen, L. N., Shaparis, A. B., \& Bolin, H. (1974). Effect of potassium sorbate on Salmonellae, Staphylococcus aureus and Clostridium botulinum in cooked, uncured sausage. Applied Microbiology, 28, 262-264. 